\title{
Chinese plan pins big hopes on small science
}

David Cyranoski, Beijing

When the Chinese Academy of Sciences presented a self-cleaning 'nano-necktie' to China's president, Jiang Zemin, last December, it provided a boost to the country's high hopes for nanotechnology.

The technology behind the tie, developed by Lei Jiang at the Chinese Academy of Sciences' Institute of Chemistry in Beijing, combines water-repellent and oil-repellent nanometre-scale structures on its surface. Such combinations have a wide range of analogous applications, claims Jiang. And it is this kind of potential that has caught the attention of the Chinese government.

Taking its cue from recently established programmes in the United States and Japan, the government now plans to spend an estimated 2.5 billion renminbi (US $\$ 300$ million) over five years on nanoscience.

The scheme includes construction of a National Nanoscience Center in Beijing, scheduled to be fully operational in 2003. Its planners hope that the centre will be a focal point for China's research efforts in nanotechnology, encompassing basic research in nanoscale physics, chemistry and biology.

"It will be a platform that scientists throughout China and the world can use," says Chunli Bai, vice-president of the Chinese Academy of Sciences and a member of the country's national steering commission for nanotechnology.

The centre will also help to bring scientific talent back home to China and foster a multidisciplinary approach to research. "I have watched too many excellent students go overseas, now I want to attract some of them to stay," says Xing Zhu, a physicist at Peking University, who is helping to plan the facility.

"We will have an international advisory committee to establish a world-class laboratory, and we hope to draw many foreign researchers here," Bai adds.

Teams selected by the centre's committee of scientists and government officials will be invited to use the facility, carrying out research on the manipulation of materials at the molecular level.

Officials will next month set the budget for the centre. Construction and equipment are expected to cost between 250 million and 500 million renminbi, and the centre will cost up to 15 million renminbi a year to run. The money will come from several government agencies.

The centre was proposed in a July report by various government bodies, which also called for two separate nanoengineering facilities, in Beijing and Shanghai, for application and commercialization. Plans to establish these centres are in the works.

Technology transfer to industry, either through the nanoengineering centres or directly, will be a major goal of the nanoscience centre, according to Bai.

"Integrating engineering with science will be challenging in China," says Zhong Lin Wang, a materials researcher at the Georgia Institute of Technology in Atlanta, who has been collaborating with some Chinese universities on nanotechnology. "The key to success will be collaboration, which has been a weakness in the Chinese community, but I do see some promising changes in recent years."

But some scientists are worried that the nano-necktie has raised expectations for eyegrabbing commercial products. "We should be appealing to real basic science, not this kind of propaganda," one sceptic argues.

\section{Polar bears fuel row over Alaskan oil}

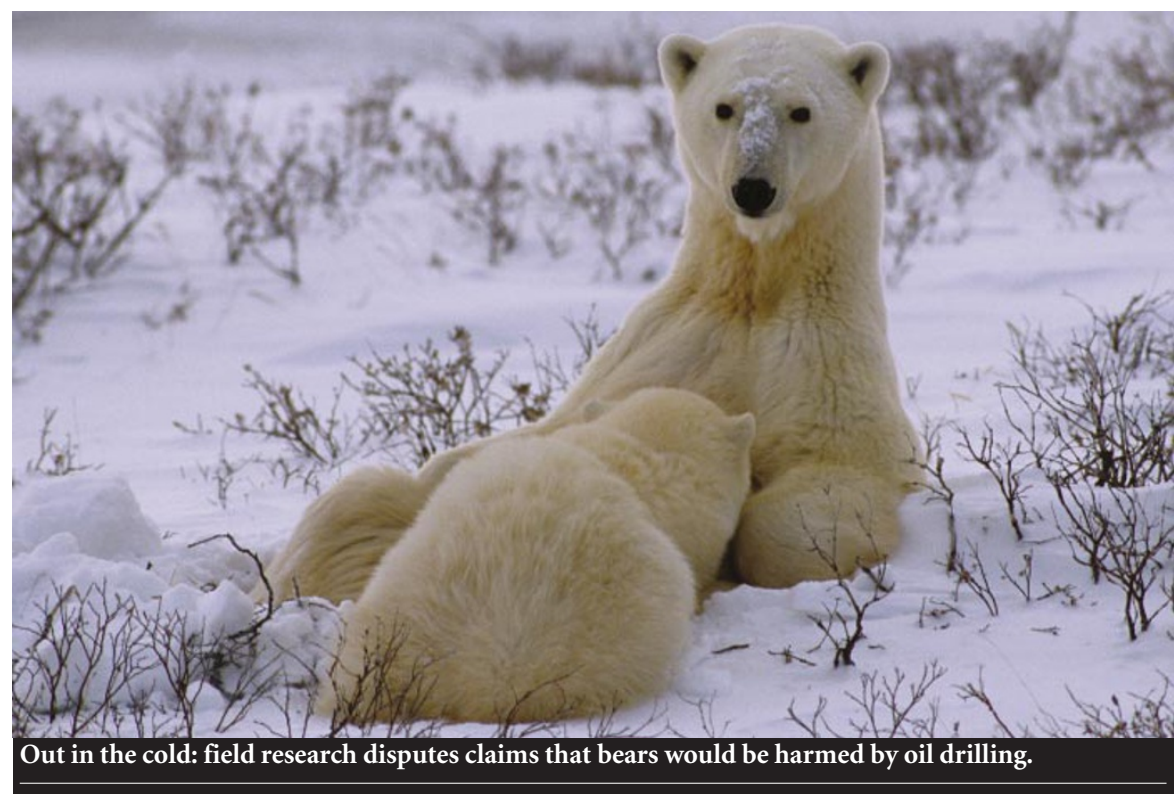

Mark Schrope

Polar bears are the latest flashpoint in the intensifying fight over whether the United States should drill for oil in Alaska's Arctic National Wildlife Refuge (ANWR).

President George W. Bush has reaffirmed the case for the drilling — in the name of energy security - since the events of 11 September. But environmentalists, facing an uphill struggle to block it, are threatening to sue the administration for allegedly covering up information on the impact of such drilling on the polar bear population.

Research does not seem to back the environmentalists' claims, however. Recent studies - albeit part-funded by the oil industry - suggest that mother polar bears will not abandon their young as a result of oil exploration and extraction.

Steven Amstrup, a biologist with the US Geological Survey in Anchorage, has surveyed polar bears in Alaska for over a decade. He estimates that about 25 dens are set up by the bears each year in the region of the ANWR where drilling is set to take place.

Environmentalists argue that drilling might disturb some female polar bears so much that they abandon their dens and cubs.
But Amstrup, whose assessment is partly based on data showing that dens are widely dispersed, says that activity in a given area would disrupt few, if any, bears.

In earlier work, Amstrup found that the bears are generally tolerant of outside disturbance (see Arctic 46, 246-250; 1993). High-impact activities could also be prevented during the denning season. "There are a lot of options for management," he says.

The Center for Biological Diversity, an environmental pressure group based in Tucson, Arizona, has nonetheless petitioned the US Department of the Interior to release a 1995 assessment of whether the United States complies with a 1973 international agreement to protect polar bears. Congress requested the report but has yet to receive it, as the interior department says it wants to retain it until a new polar bear treaty, agreed with Russia last year, is reviewed by the Bush administration.

Kieran Suckling, the centre's executive director, calls this a "stall tactic" and says the group may use legal means to force the document's release. He believes the report suggests that development in the ANWR could break the 1973 agreement. 